\title{
USING FUZZY CHOQUET INTEGRAL OPERATOR FOR SUPPLIER SELECTION WITH ENVIRONMENTAL CONSIDERATIONS
}

\author{
Arash SHAHRYARI NIA ${ }^{1}$, Laya OLFAT $^{1}$, Ahmad ESMAEILI ${ }^{1}$, \\ Reza ROSTAMZADEH ${ }^{2}$, Jurgita ANTUCHEVIČIENË ${ }^{3}$ \\ ${ }^{1}$ Industrial Management Department, Faculty of Management and Accounting, Allameh \\ Tabataba'i University, Dehkadeh-ye-Olympic (Campus), Tehran, Iran \\ ${ }^{2}$ Department of Management, Urmia Branch, Islamic Azad University, Urmia, Iran \\ ${ }^{3}$ Department of Construction Technology and Management, \\ Faculty of Civil Engineering, Vilnius Gediminas Technical University, \\ Sauletekio al. 11, 10223 Vilnius, Lithuania \\ E-mail: ${ }^{3}$ jurgita.antucheviciene@vgtu.lt (corresponding author)
}

Received 21 January 2016; accepted 23 May 2016

\begin{abstract}
The increasing importance of considering environmental issues as a part of the corporate social responsibility, which has environmental and social impacts as well as affects the image and competitiveness of a firm, has encouraged companies to revise their major processes of supply chain management (SCM). Since the performance of a company heavily relies on its suppliers, it is of vital importance to incorporate environmental criteria into supplier selection problem to satisfy both conventional and environmental criteria, which have only been considered by a limited number of studies. Therefore, following a brief review of green supply chain management (GSCM) and sustainable supply chain management (SSCM) concepts and investigation of supplier selection approaches, this study after focuses on a modified Delphi method that has been applied to determine supplier selection criteria. Also, the intuitionistic fuzzy value (IFV) and interval value intuitionistic fuzzy (IVIF) have been utilised for supplier evaluation regarding the subjective nature and uncertainty of judgment. By using the Choquet Integral operator and fuzzy measures, the best supplier has been selected, and the comparison between IFV and IVIF has been made. This methodology has been applied to a manufacturing company to assess the applicability of the proposed methodology. The proposed methodology can be used for real world problems that contain fuzziness or interacting decision criteria. Moreover, due to a high level of expert involvement in the decision-making process, we claimed that the knowledge of experts has been utilised constructively.
\end{abstract}

Keywords: supplier selection, sustainable supply chain, green supply chain, Delphi method, intuitionistic fuzzy value, Choquet Integral operator.

JEL Classification: C61, D81, L62, Q01, Q50. 


\section{Introduction}

In recent years, the characteristics of marketplaces have changed. Now, customers demand quicker delivery, higher quality, better price and greater service excellence. Moreover, environmental issues have guided organisations to take into account their environmental management (Sahu et al. 2012). The last ten years indicate an increase in consolidation of SCM and environmental management (Lee et al. 2012). SCM sets up and controls the flows of money, components, processes and information; however, due to changes in non-governmental organisations (NGOs) as well as the attitude and awareness of people and legislators towards the environmental impact of industrial activities, firms cannot neglect environmental challenges (Büyüközkan, Çifçi 2012). To cope with the issue, companies have employed different programmes and practices to guarantee that vendors supply high-quality services and materials that are in line with environmental standards (Kannan et al. 2013). Special attention is given to the convergence of green and SSCM (Büyüközkan, Çifçi 2011). The terms GSCM and SSCM are to link the concepts of SCM with sustainability or environmental consideration. Definitions of SSCM and GSCM noticeably overlap: "it is argued that SSCM is essentially an extension of GSCM" (Ahi, Searcy 2013). Within the supply chain (SC) practices, supplier selection as a key function consists of assessment, ranking, and selection of the best supplier among potential alternatives, especially when criteria are typically conflicting. Many studies have shown that the business performance and the customer satisfaction are noticeably affected by supplier selection (Shemshadi et al. 2011). The supplier selection studies encounter three main challenges: (i) the collection of criteria from various sources suited to the needs of the company, in which case comprehensive criteria are not met. This problem is partly caused by a lack of expert knowledge on the importance of new perspectives, such as sustainability or environmental consideration, or a limitation in methods to consider large numbers of criteria. (ii) The subjective nature of human judgment, which is a prerequisite for the evaluation processes. The expert opinions about the weights of criteria and the evaluation of each alternative inherently contain some uncertainties. And the last challenge is (iii) to capture the interactions or dependencies between the criteria. In order to cope with these challenges, the authors have utilised a research process to include a large number of criteria divided into main groups; and on the next level, they have used fuzzy values and fuzzy measures to evaluate these criteria. Also, the interactions of the criteria have been captured by the Choquet integral.

The rest of the paper is structured as follows: in Section 1, SSCM and GSCM concepts are introduced and supplier selection approaches are reviewed. The research process, various stages and methods are described in Section 2. Section 3 reviews an application of the proposed methodology in a manufacturing firm to validate the method. The results are put forward in last Section. 


\section{Literature review}

\subsection{Brief review of GSCM \& SSCM}

The SCM term appeared in the early 1980s, earned enough attention and evolved during past three decades. Nowadays, companies have accepted a high level of commitment to sustainability as a consequence of great pressures from different stakeholders, NGOs and global competition (Hassini et al. 2012). The triple bottom line (TBL) approach defines sustainability by the dimensions of the natural environment, society, and economic performance. The TBL approach suggests that the positive economic performance alone is not enough; therefore, organisations must take action so as to have a positive effect on the society and the environment. It means that a firm's long-term survival and profitability could be outstandingly achieved by readjusting these goals with social and environmental goals (Dao et al. 2011). It is an accepted fact that SSCM is a theoretical and practical broadening of SCM (Beske, Seuring 2014). Seuring and Muller (2008) described SSCM as "the management of material, information and capital flows as well as cooperation among companies along the supply chain while taking goals from all three dimensions of sustainable development, i.e., economic, environmental and social, into account which are derived from customer and stakeholder requirements. In sustainable supply chains, environmental and social criteria need to be fulfilled by the members to remain within the supply chain, while it is expected that competitiveness would be maintained through meeting customer needs and related economic criteria". Gupta and Palsule-Desai (2011) have explained the concept of SSCM in three steps: firms must consider (1) the environmental impact of their activities as an essential element of their performance, not as imposed constraints as well as (2) the environmental impact of all members of the value chain; besides, (3) the perspective of firms on sustainability must go beyond a narrow functional perspective and embrace issues, problems and solutions across functional boundaries. Ahi and Searcy (2013) represented a definition of SSCM as "Creating coordinated SC by the voluntary integration of economic, environmental, and social considerations with key inter-organisational business systems designed to effectively and efficiently manage the material, information, and capital flows associated with the procurement, production and distribution of services or products in order to meet stakeholder requirements and improve the profitability, competitiveness, and resilience of the organisation over the short and long-term". Esfahbodi et al. (2016) in their definition of SSCM have emphasised the product life-cycle stages in order to minimise the negative environmental impact.

As a way of reducing environmental impacts and improving ecological efficiency, GSCM means that companies should add environmental and social criteria to their SCM and to adjust their SC accordingly (Büyüközkan, Çifçi 2012). Two main approaches of greening supply chains are mentioned in literature as monitoring and collaboration (Tachizawa et al. 2015). The concept of GSCM commonly indicates that environmental performance of suppliers must be checked, and the collaboration can only continue if the suppliers have enough capability to satisfy environmental standards (Kannan et al. 2013). In other words, GSCM aims to remove negative environmental impacts 
or reduce resource depletion across the SC encompassing first stages to the final stages in order to reduce different incurred costs and to improve the competitive advantage (Govindan et al. 2013). Sarkis et al. (2011) have reported nine theories used to study various aspects of GSCM including ecological modernisation, complexity, institutional, information, resource dependence, resource-based view, stakeholder, social network, and transaction cost economics theories. Srivastava (2007) described GSCM as "adding environmental thought into SCM activities from product design to used products endof-life management". Ahi and Searcy (2013) analysed 22 distinct definitions of GSCM in 124 academic articles and concluded that a distinguished definition of GSCM is not absolutely required because definitions of GSCM and SSCM are alike, but SSCM would incorporate the social and economic dimensions.

\subsection{Supplier selection approaches}

Supplier selection is a research topic that has been studied extensively during the last decade by different approaches and criteria. To the best of our knowledge based on an investigation of the following papers, there are at least five worthwhile research papers comprehensively investigating the literature on supplier selection (Jain et al. 2009; Chai et al. 2013; Ho et al. 2010; Wu, Barnes 2011; Govindan et al. 2015). Studies are available on the subject that the researchers have tried to give a comprehensive glimpse of the past and current research agenda. The various techniques and approaches, which are used to select green suppliers, are listed and reviewed in Table 1.

\section{Methodology}

This study proposes an approach based on a modified Delphi method and the fuzzy Choquet integral for supplier selection with environmental consideration.

\subsection{Modified Delphi method}

Achieving the most definite and reliable consensus of anonymous experts is the objective of the Delphi method. The Delphi method is composed of five rounds: (1) choosing the anonymous experts to make the expert panel; (2) handling the first round of a survey; (3) handling the second round of a questionnaire survey; (4) handling the third round of a questionnaire survey; (5) merging the expert opinions to achieve a consensus. Rounds (3) and (4) must be repeated until a consensus is reached. The number of experts could be between 5 and 50, and other researchers have expressed this number could be between 10 and 30 (Okoli, Pawlowski 2004; Gumus 2009).

\subsection{Choquet integral and the applications}

The usefulness of Choquet integral in measuring the expected utility of an uncertain event and its capability to illustrate the dependencies or interactions among criteria is expressed by Xu (2010) from Grabisch's notable example "evaluation in high school". Grabisch (1995) explained that "we want to assess a group of students in terms of three subjects: \{mathematics, physics, literature\}, the science-related subjects are more important than literature, but simultaneously, the students who are good in both literature and each of science-related subjects have an advantage against other students". 

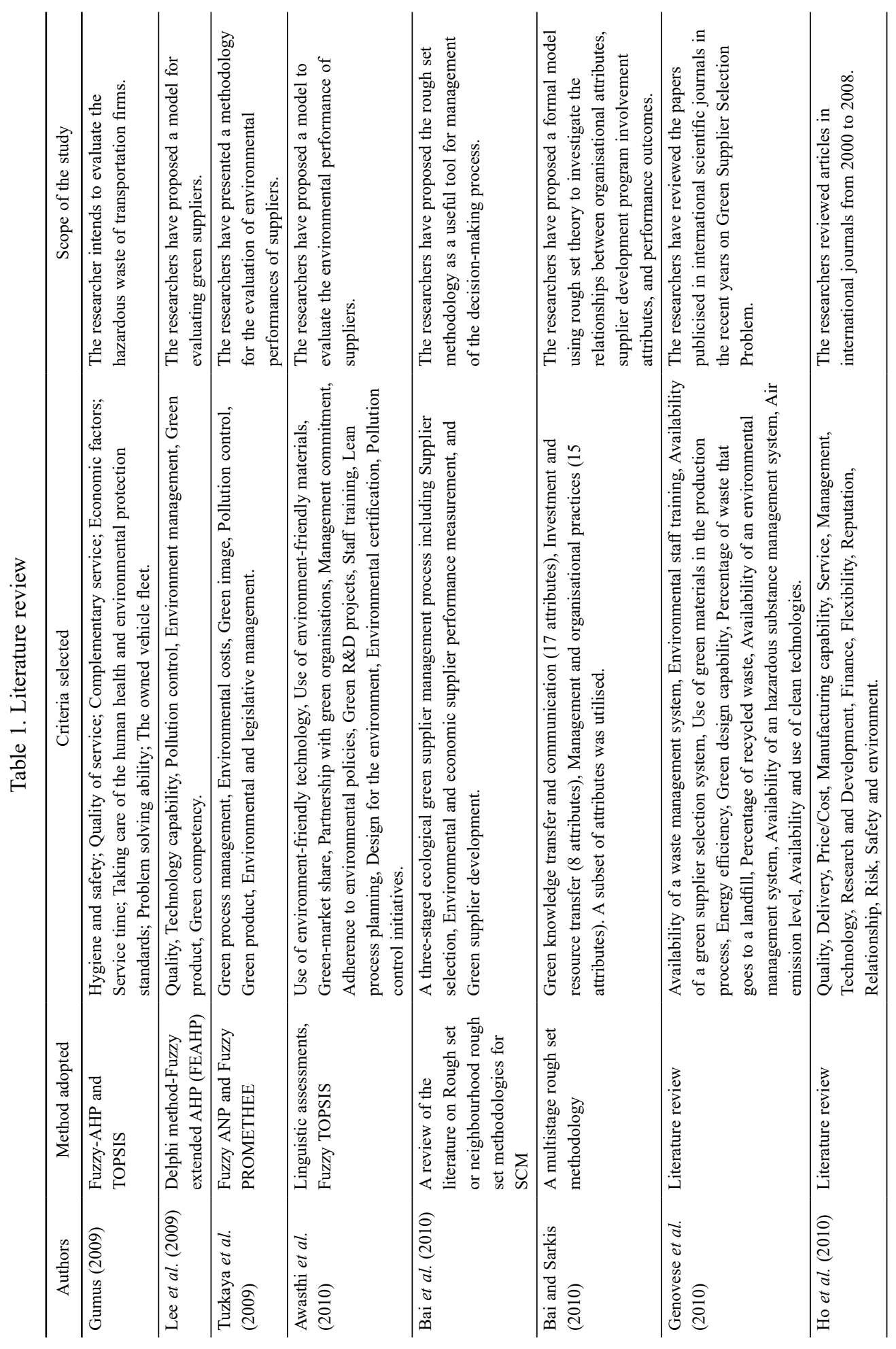


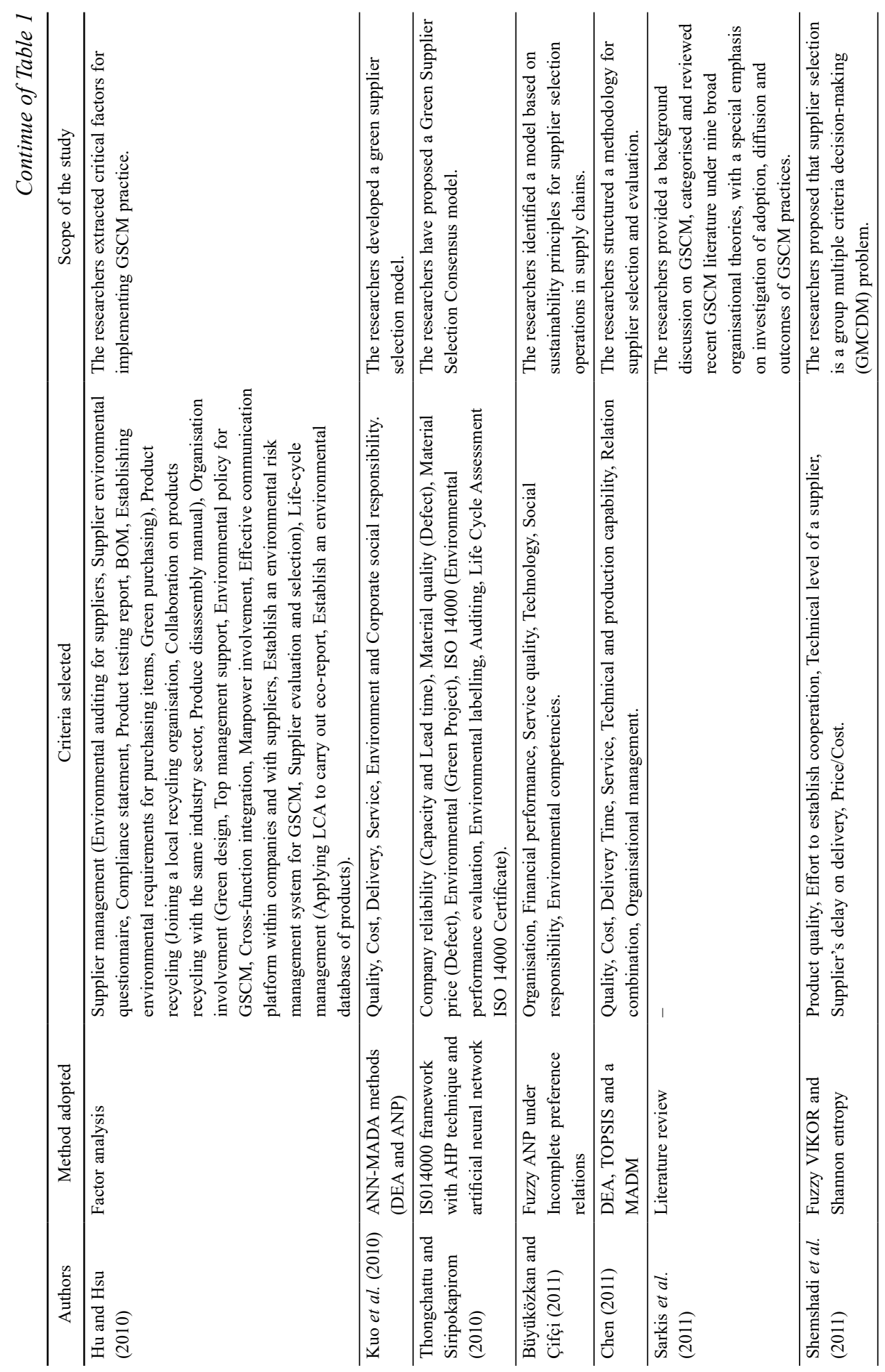




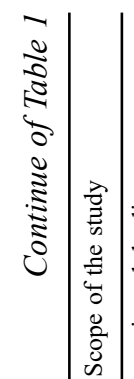

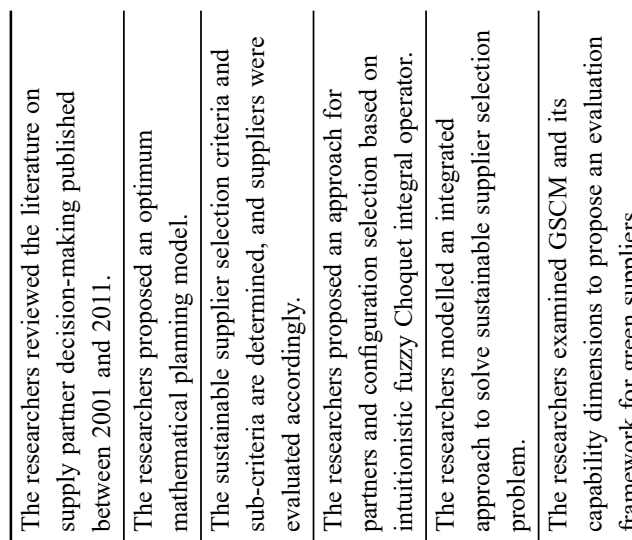

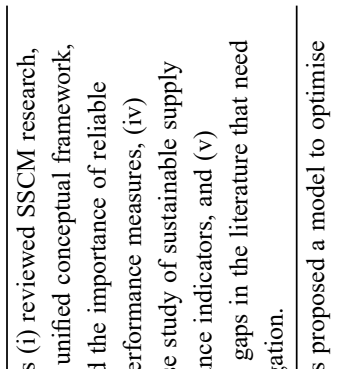

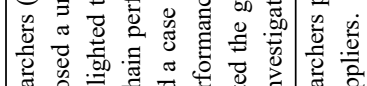

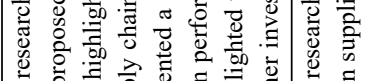

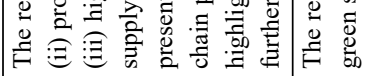

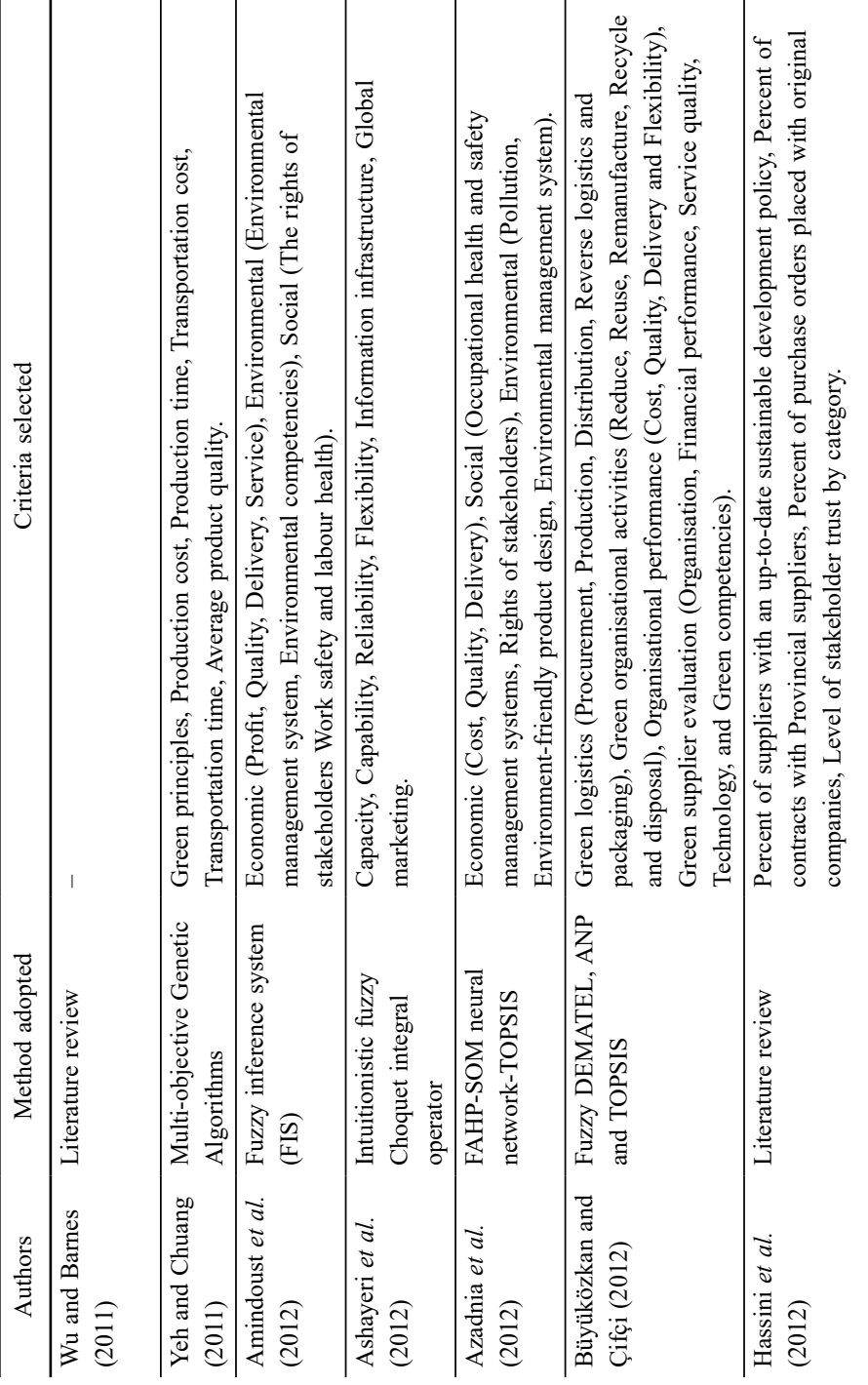

i

离 产

¿

这

강

.ే.

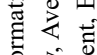

递家

客㝴

बे

(5)

ฮु

돈

可

욯

音皆

흠

㻤

产高

总氜卙

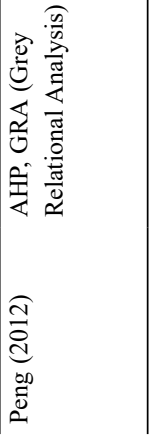




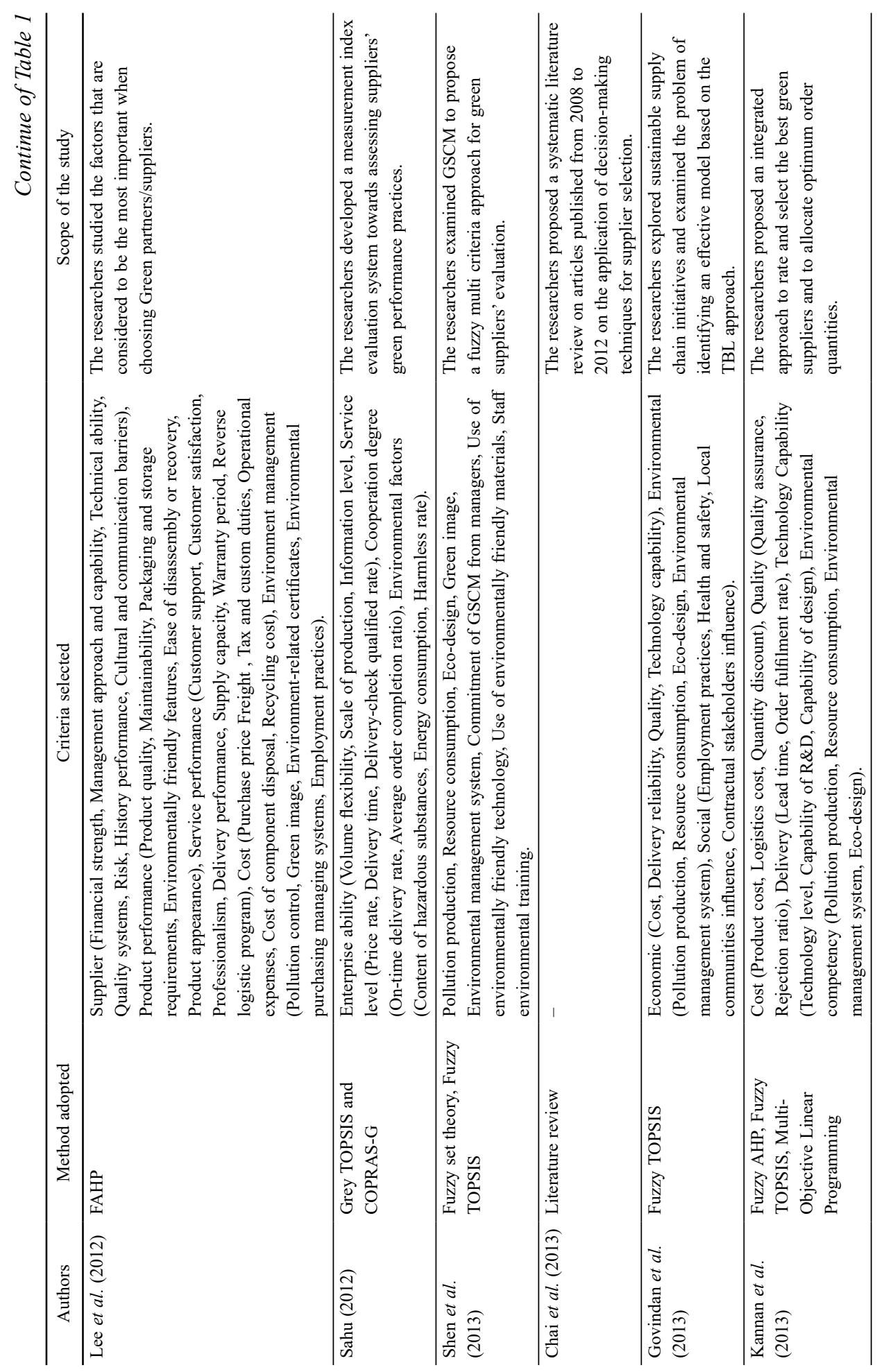




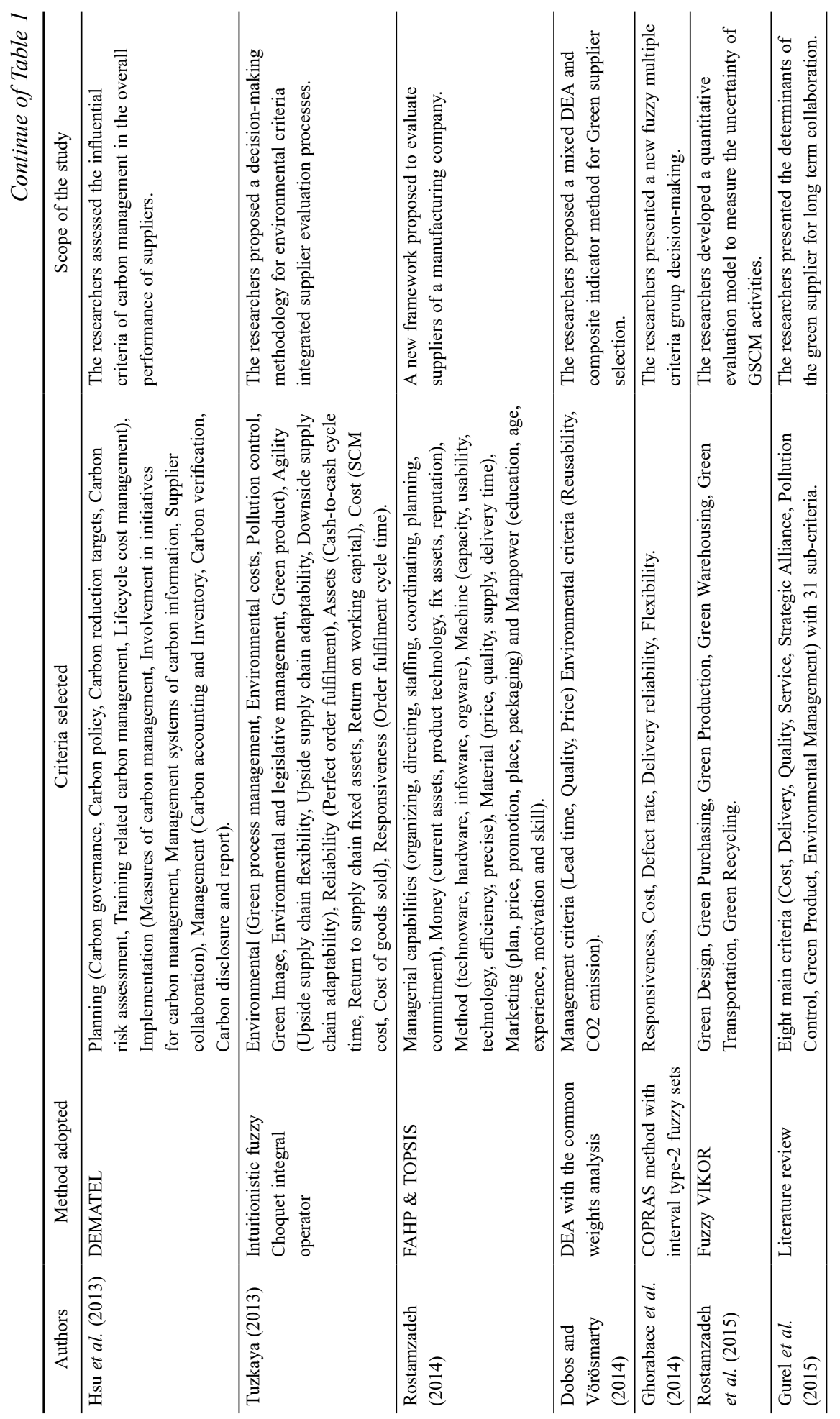




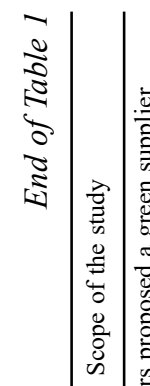

焉

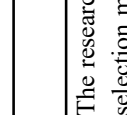

(4)

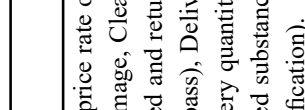

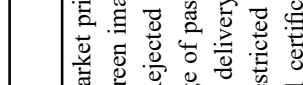

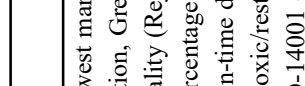

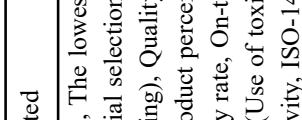

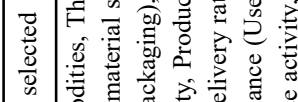

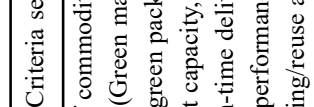

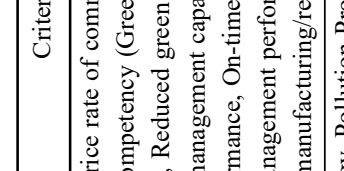

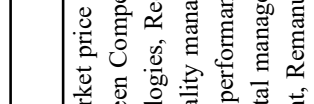

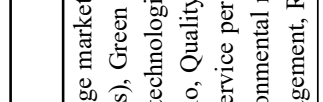

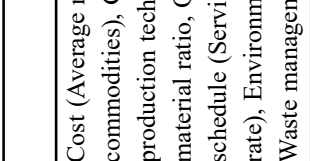

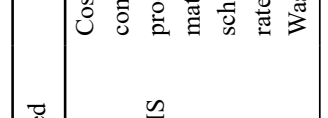

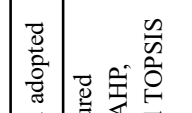

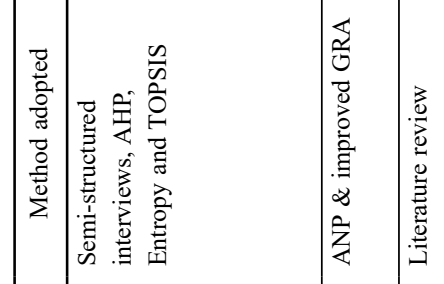

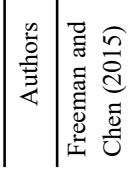

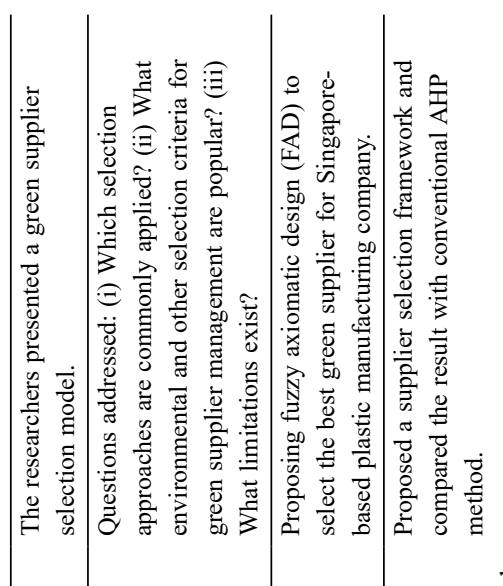

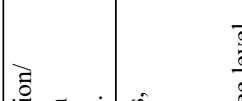

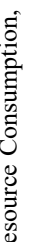

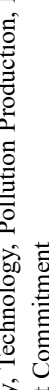

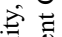

ప

نี

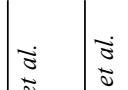

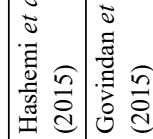

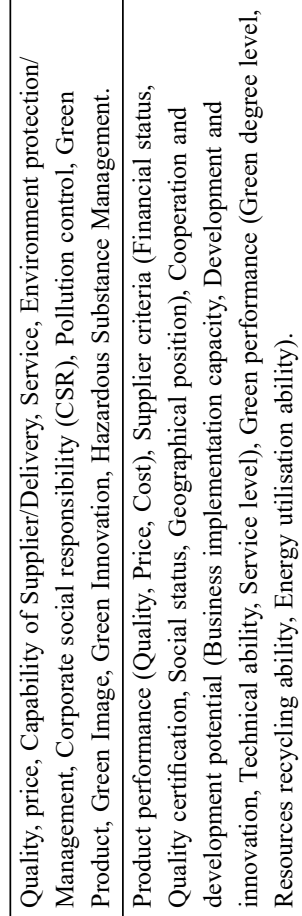

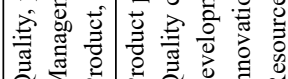

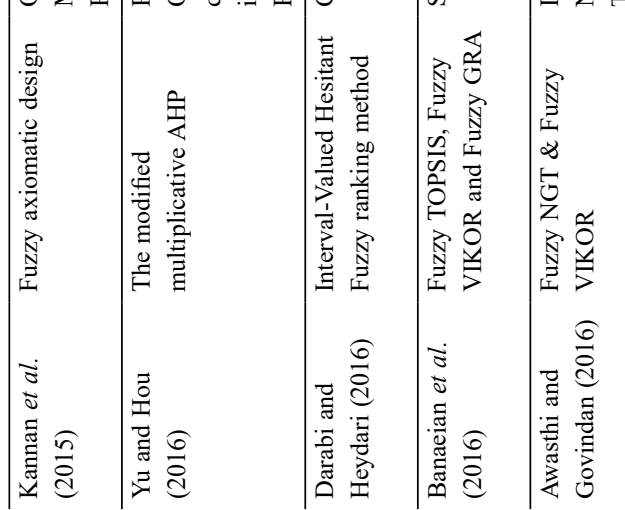

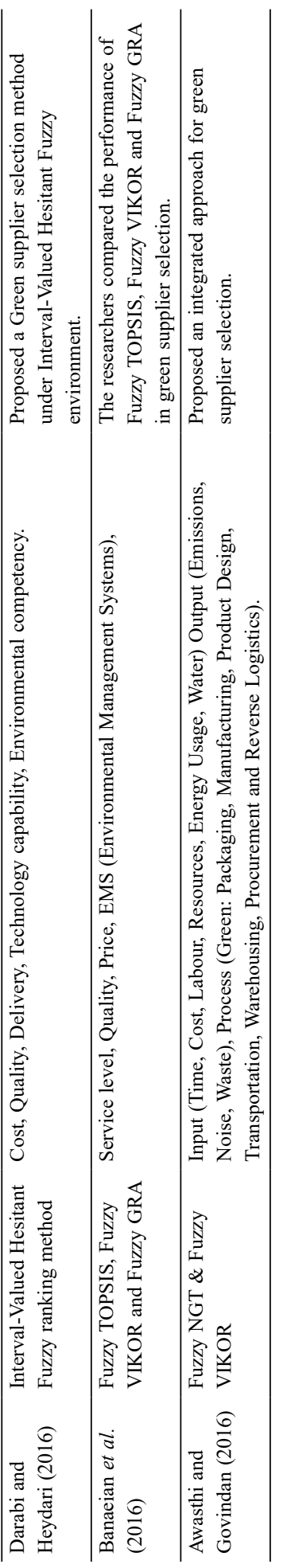


In this respect, the dependency between criteria can be captured through the Choquet integral (Grabisch 1995; Xu 2010; Ashayeri et al. 2012). So far, Choquet integral and its derivatives have been applied for the various decision-making problems as shown in Table 2.

Table 2. Application of Choquet operator in decision-making problems

\begin{tabular}{ll}
\hline \multicolumn{1}{c}{ Source } & \multicolumn{1}{c}{ Used problem } \\
\hline Srivastava et al. (2008) & Nonlinear system modelling \\
\hline Shieh et al. (2009) & Student performance evaluation \\
\hline Ashayeri et al. (2012) & Supply chain partner selection \\
\hline Qin, Liu (2013) & IIF-MAGDM based on Choquet integral \\
\hline Tuzkaya (2013) & Supplier evaluation with environmental criteria \\
\hline Wu et al. (2014) & Solar thermal power plant site selection \\
\hline
\end{tabular}

Recently, some fuzzy aggregation operators based on Choquet integral have been presented by Tan and Chen (2010), Xu (2010) and Yu et al. (2015), which have considered both elements of importance and the correlations or dependencies of the elements. Based on TOPSIS, Tan (2011) developed an IVIF technique with the Choquet integral related Hamming distance for group decision making. Park et al. (2011) also extended the TOPSIS, Zavadskas et al. $(2014,2015)$ developed MULTIMOORA and WASPAS methods for decision making under the IVIF environment.

\subsection{Intuitionistic fuzzy sets (IFS)}

Before the presentation of these methodologies, some basic definitions of IFSs and IVIFs have to be presented. Since Zadeh (1965) introduced his famous theory of a fuzzy set, many extensions of his fuzzy set theory have been developed and been utilised for solving decision-making problems under vagueness or uncertainty. In 1986, Atanassov presented a new extension of Zadeh's fuzzy sets and called it "the intuitionistic fuzzy sets". Each element in an IFS is shown by an ordered pair, and each ordered pair is defined by a membership degree and a non-membership degree. The sum of the two degrees of each ordered pair must be less than or equal to one (Tan, Chen 2010; Xu 2010).

Suppose a fixed set $X=\left\{x_{1}, x_{2}, \ldots, x_{n}\right\}$, an IFS is defined as (Xu 2010):

$$
A=\left\{\left\langle x_{i}, t_{A}\left(x_{i}\right), f_{A}\left(x_{i}\right)\right\rangle \mid x_{i} \in X\right\},
$$

which assigns to each element $x_{i}$ a membership degree $t_{A}\left(x_{i}\right)$ and a non-membership degree $f_{A}\left(x_{i}\right)$ under the condition

$$
0 \leq t_{A}\left(x_{i}\right)+f_{A}\left(x_{i}\right) \leq 1 \text {, for all } x_{i} \in X .
$$

An ordered pair $\alpha x_{i}=t_{\alpha} x_{i}, f_{\alpha} x_{i}$ is called an intuitionistic fuzzy value (IFV) if it could satisfy the condition below:

$$
t_{\alpha}\left(x_{i}\right) \in[0,1], \quad f_{\alpha}\left(x_{i}\right) \in[0,1], t_{\alpha}\left(x_{i}\right)+f_{\alpha}\left(x_{i}\right) \leq 1 .
$$


$\mathrm{Xu}(2010)$ gave some useful operations on IFVs, as follows:

Let $\alpha\left(x_{i}\right)=\left(t_{\alpha}\left(x_{i}\right), f_{\alpha}\left(x_{i}\right)\right)$ and $\alpha\left(x_{j}\right)=\left(t_{\alpha}\left(x_{j}\right), f_{\alpha}\left(x_{j}\right)\right)$ be two IVFs; then

$$
\begin{gathered}
\alpha\left(x_{i}\right) \oplus \alpha\left(x_{j}\right)=\left(t_{\alpha}\left(x_{i}\right)+t_{\alpha}\left(x_{j}\right)-t_{\alpha}\left(x_{i}\right) t_{\alpha}\left(x_{j}\right), f_{\alpha}\left(x_{i}\right) f_{\alpha}\left(x_{j}\right)\right) ; \\
\alpha\left(x_{i}\right) \otimes \alpha\left(x_{j}\right)=\left(t_{\alpha}\left(x_{i}\right) t_{\alpha}\left(x_{j}\right), f_{\alpha}\left(x_{i}\right)+f_{\alpha}\left(x_{j}\right)-f_{\alpha}\left(x_{i}\right) f_{\alpha}\left(x_{j}\right)\right) ; \\
\lambda \alpha\left(x_{i}\right)=\left(1-\left(1-t_{\alpha}\left(x_{i}\right)\right)^{\lambda},\left(f_{\alpha}\left(x_{i}\right)\right)^{\lambda}\right), \lambda>0 ; \\
\left(\alpha\left(x_{i}\right)\right)^{\lambda}=\left(\left(t_{\alpha}\left(x_{i}\right)\right)^{\lambda}, 1-\left(1-f_{\alpha}\left(x_{i}\right)\right)^{\lambda}\right), \lambda>0 .
\end{gathered}
$$

For comparing any two IFVs, the concepts of the score function and accuracy function will be used (Tan and Chen 2010). Xu (2010) clarified this comparison method as follows:

Let $\alpha\left(x_{i}\right)=\left(t_{\alpha}\left(x_{i}\right), f_{\alpha}\left(x_{i}\right)\right)$ and $\alpha\left(x_{j}\right)=\left(t_{\alpha}\left(x_{j}\right), f_{\alpha}\left(x_{j}\right)\right)$ be two IVFs, then $s\left(\alpha\left(x_{i}\right)\right)=t_{\alpha}\left(x_{i}\right)-f_{\alpha}\left(x_{i}\right)$ and $s\left(\alpha\left(x_{j}\right)\right)=t_{\alpha}\left(x_{j}\right)-f_{\alpha}\left(x_{j}\right)$ be the score of $\alpha\left(x_{i}\right)$ and $\alpha\left(x_{j}\right)$, respectively, and let $h\left(\alpha\left(x_{i}\right)\right)=t_{\alpha}\left(x_{i}\right)+f_{\alpha}\left(x_{i}\right)$ and $h\left(\alpha\left(x_{j}\right)\right)=t_{\alpha}\left(x_{j}\right)+f_{\alpha}\left(x_{j}\right)$ be the accuracy degrees of $\alpha\left(x_{i}\right)$ and $\alpha\left(x_{j}\right)$ respectively; then

if $s\left(\alpha\left(x_{i}\right)\right)<s\left(\alpha\left(x_{j}\right)\right)$, then $\alpha\left(x_{i}\right)$ is smaller than $\alpha\left(x_{j}\right)$, denoted by $\alpha\left(x_{i}\right)<\alpha\left(x_{j}\right)$, if $s\left(\alpha\left(x_{i}\right)\right)=s\left(\alpha\left(x_{j}\right)\right)$, then

if $h\left(\alpha\left(x_{i}\right)\right)=h\left(\alpha\left(x_{j}\right)\right)$, then $\alpha\left(x_{i}\right)$ and $\alpha\left(x_{j}\right)$ represent the same information,

i.e., $t_{\alpha}\left(x_{i}\right)=t_{\alpha}\left(x_{j}\right)$ and $f_{\alpha}\left(x_{i}\right)=f_{\alpha}\left(x_{j}\right)$, denoted by $\alpha\left(x_{i}\right)=\alpha\left(x_{j}\right)$,

if $h\left(\alpha\left(x_{i}\right)\right)<h\left(\alpha\left(x_{j}\right)\right)$, then $\alpha\left(x_{i}\right)$ is smaller than $\alpha\left(x_{j}\right)$, denoted by $\alpha\left(x_{i}\right)<\alpha\left(x_{j}\right)$.

The relation between the score function $\mathrm{S}$ and the accuracy function $\mathrm{h}$ is similar to the relation between the mean and variance in statistics ( $\mathrm{Xu} 2010)$.

\subsection{Interval-valued intuitionistic fuzzy sets (IVIFS)}

In 1989, Atanassov and Gargov presented a new extension of IFS, which membership function and non-membership function were intervals instead of exact numbers and could not be specified accurately (Tan 2011; Xu 2010) because of expressing membership function and non-membership function as intervals the IVIFS are more suitable to overcome the fuzziness of an uncertain environment.

Suppose a fixed set $X=\left\{x_{1}, x_{2}, \ldots, x_{n}\right\}$, then an IVIFS $\tilde{A}$ over $X$ is an object of the form:

$$
\tilde{A}=\left\{\left\langle x_{i}, \tilde{t}_{\tilde{A}}\left(x_{i}\right), \tilde{f}_{\tilde{A}}\left(x_{i}\right)\right\rangle \mid x_{i} \in X\right\},
$$

where $\tilde{t}_{\tilde{A}}\left(x_{i}\right) \subset[0,1]$ and $\tilde{f}_{\tilde{A}}\left(x_{i}\right) \subset[0,1]$ are intervals, and for every $x_{i} \in X$ $0 \leq \sup t_{A}\left(x_{i}\right)+\sup f_{A}\left(x_{i}\right) \leq 1$.

The ordered pair $\tilde{\alpha}\left(x_{i}\right)=\left(\tilde{t}_{\tilde{\alpha}}\left(x_{i}\right), \tilde{f}_{\tilde{\alpha}}\left(x_{i}\right)\right)$ is called an interval-valued intuitionistic fuzzy value (IVIFV), and an IVIFV is denoted by $\tilde{\alpha}\left(x_{i}\right)=\left(\left[a\left(x_{i}\right), b\left(x_{i}\right)\right],\left[c\left(x_{i}\right), d\left(x_{i}\right)\right]\right)$ if 


$$
\left[a\left(x_{i}\right), b\left(x_{i}\right)\right] \subset[0,1],\left[c\left(x_{i}\right), d\left(x_{i}\right)\right] \subset[0,1], b\left(x_{i}\right)+d\left(x_{i}\right) \leq 1 .
$$

For any two IVIFVs $\tilde{\alpha}\left(x_{i}\right)=\left(\left[a\left(x_{i}\right), b\left(x_{i}\right)\right],\left[c\left(x_{i}\right), d\left(x_{i}\right)\right]\right)$ and $\tilde{\alpha}\left(x_{j}\right)=\left(\left[a\left(x_{j}\right), b\left(x_{j}\right)\right],\left[c\left(x_{j}\right), d\left(x_{j}\right)\right]\right)$ we have some operation as follows:

$$
\begin{gathered}
\tilde{\alpha}\left(x_{i}\right) \oplus \tilde{\alpha}\left(x_{j}\right)=\left(\left[a\left(x_{i}\right)+a\left(x_{j}\right)-a\left(x_{i}\right) a\left(x_{j}\right), b\left(x_{i}\right)+\right.\right. \\
\left.\left.b\left(x_{j}\right)-b\left(x_{i}\right) b\left(x_{j}\right)\right],\left[c\left(x_{i}\right) c\left(x_{j}\right), d\left(x_{i}\right) d\left(x_{j}\right)\right]\right) ; \\
\tilde{\alpha}\left(x_{i}\right) \otimes \tilde{\alpha}\left(x_{j}\right)=\left(\left[a\left(x_{i}\right) a\left(x_{j}\right), b\left(x_{i}\right) b\left(x_{j}\right)\right],\left[c\left(x_{i}\right)+\right.\right. \\
\left.\left.c\left(x_{j}\right)-c\left(x_{i}\right) c\left(x_{j}\right), d\left(x_{i}\right)+d\left(x_{j}\right)-d\left(x_{i}\right) d\left(x_{j}\right)\right]\right) ; \\
\left.\lambda \tilde{\alpha}\left(x_{i}\right)=\left(\left[1-\left(1-a\left(x_{i}\right)\right)^{\lambda}, 1-\left(1-b\left(x_{i}\right)\right)^{\lambda}\right],\left[\left(c\left(x_{i}\right)\right)^{\lambda}, d\left(x_{i}\right)\right)^{\lambda}\right]\right), \lambda>0 ; \\
\left.\left(a\left(x_{i}\right)\right)^{\lambda}=\left(\left[\left(a\left(x_{i}\right)\right)^{\lambda}, b\left(x_{i}\right)\right)^{\lambda}\right],\left[1-\left(1-c\left(x_{i}\right)\right)^{\lambda}, 1-\left(1-d\left(x_{i}\right)\right)^{\lambda}\right]\right), \lambda>0 .
\end{gathered}
$$

For comparing any two IVIFVs, the following method will be used:

Let $\tilde{\alpha}\left(x_{i}\right)=\left(\left[a\left(x_{i}\right), b\left(x_{i}\right)\right],\left[c\left(x_{i}\right), d\left(x_{i}\right)\right]\right)$ and $\tilde{\alpha}\left(x_{j}\right)=\left(\left[a\left(x_{j}\right), b\left(x_{j}\right)\right],\left[c\left(x_{j}\right), d\left(x_{j}\right)\right]\right)$

be two IVIFVs: $s\left(\tilde{\alpha}\left(x_{i}\right)\right)=\frac{1}{2}\left(a\left(x_{i}\right)-c\left(x_{i}\right)+b\left(x_{i}\right)-d\left(x_{i}\right)\right)$ and $s\left(\tilde{\alpha}\left(x_{j}\right)\right)=\frac{1}{2}\left(a\left(x_{j}\right)-c\left(x_{j}\right)+b\left(x_{j}\right)-d\left(x_{j}\right)\right)$ be the scores of $\tilde{\alpha}\left(x_{i}\right)$ and $\tilde{\alpha}\left(x_{j}\right)$, and let $h\left(\tilde{\alpha}\left(x_{i}\right)\right)=\frac{1}{2}\left(a\left(x_{i}\right)+b\left(x_{i}\right)+b\left(x_{i}\right)+d\left(x_{i}\right)\right)$ and $h\left(\tilde{\alpha}\left(x_{j}\right)\right)=\frac{1}{2}\left(a\left(x_{j}\right)+b\left(x_{j}\right)+b\left(x_{j}\right)+d\left(x_{j}\right)\right)$ be the accuracy degrees of $\tilde{\alpha}\left(x_{i}\right)$ and $\tilde{\alpha}\left(x_{j}\right)$, respectively; then:

- if $s\left(\tilde{\alpha}\left(x_{i}\right)\right) \leq s\left(\tilde{\alpha}\left(x_{j}\right)\right)$ then $\tilde{\alpha}\left(x_{i}\right)$ is smaller than $\tilde{\alpha}\left(x_{j}\right)$, denoted by $\tilde{\alpha}\left(x_{i}\right)<\tilde{\alpha}\left(x_{j}\right)$.

- If $s\left(\tilde{\alpha}\left(x_{i}\right)\right)=s\left(\tilde{\alpha}\left(x_{j}\right)\right)$, then

- (1) if $h\left(\tilde{\alpha}\left(x_{i}\right)\right)=h\left(\tilde{\alpha}\left(x_{j}\right)\right)$, then $\tilde{\alpha}\left(x_{i}\right)$ and $\tilde{\alpha}\left(x_{j}\right)$ represent the indifference information, denoted by $\tilde{\alpha}\left(x_{i}\right)=\tilde{\alpha}\left(x_{j}\right)$,

- (2) if $h\left(\tilde{\alpha}\left(x_{i}\right)\right)<h\left(\tilde{\alpha}\left(x_{j}\right)\right)$, then $\tilde{\alpha}\left(x_{i}\right)$ is smaller than $\tilde{\alpha}\left(x_{j}\right)$, denoted by $\tilde{\alpha}\left(x_{i}\right)<\tilde{\alpha}\left(x_{j}\right)$.

\subsection{IFC integral operator-based method for decision-making}

Here, we articulately describe the steps of the decision-making methodology based on the Choquet integral operator as follows (Tan, Chen 2010):

Step 1. In connection with criteria $c_{j}=(j=1,2, \ldots, n)$, the partial evaluation of the alternative $a_{i}=(i=1,2, \ldots, m)$ is made by an intuitionistic fuzzy value $\tilde{a}_{i j}=\left(t_{i j}, f_{i j}\right)(i=1,2, \ldots, m ; j=1,2, \ldots, n)$ and a decision-making matrix must be constructed as follows:

$$
R=\left(\begin{array}{cccc}
\tilde{a}_{11}, & \tilde{a}_{12}, & \ldots, & \tilde{a}_{1 n} \\
\tilde{a}_{21}, & \tilde{a}_{22}, & \ldots, & \tilde{a}_{2 n} \\
\ldots & \ldots & \ldots & \\
\tilde{a}_{m 1}, & \tilde{a}_{m 2}, & \ldots, & \tilde{a}_{m n}
\end{array}\right) .
$$


Step 2. Calculate $S\left(\tilde{a}_{i j}\right)$ of the partial evaluation $\tilde{a}_{i j}$ of the alternative $a_{i}=(i=1,2, \ldots, m)$, and utilise $S\left(\tilde{a}_{i j}\right)$ to rank the partial evaluation $\tilde{a}_{i j}$. If there is no difference between two score functions $S\left(\tilde{a}_{i j}\right)$ and $S\left(\tilde{a}_{i k}\right)$, then by accuracy function $H$, calculate $H\left(\tilde{a}_{i j}\right)$ and $H\left(\tilde{a}_{i k}\right)$ of the partial evaluation $\tilde{a}_{i j}$ and $\tilde{a}_{i k}$, respectively, and rank the partial evaluations $\tilde{a}_{i j}$ and $\tilde{a}_{i k}$ in accordance with accuracy degrees $H\left(\tilde{a}_{i j}\right)$ and $H\left(\tilde{a}_{i k}\right)$. So, the partial evaluation $\tilde{a}_{i j}$ of the alternative $a_{i}$ is recorded so that $\tilde{a}_{i(j)} \leq \tilde{a}_{i(j+1)}$.

Step 3. After the evaluation of criteria by experts, calculate the fuzzy measures. (In 1974, the fuzzy measure concept was developed by Sugeno as a subjective scale to specify the degrees of fuzziness. It is applicable for analysing subjective processes of humans (Chen, Wang 2001)). To determine fuzzy measures for given $n$ criteria, $2^{n}-2$ values must be calculated (Larbani et al. 2011). So, the identification of fuzzy measures is a complex process because the number of subsets is exponential. Now, there are numerous methods in literature to identify fuzzy measures that have been proposed by different researchers (Murillo et al. 2013; Larbani et al. 2011; Wang et al. 2011; Takahagi 2008; Grabisch et al. 2008; Chen et al. 2000; Grabisch 1995).

Step 4. Use the following intuitionistic fuzzy Choquet (IFC) integral operator:

$$
\operatorname{IFC}_{\mu}\left(\tilde{a}_{i 1}, \ldots, \tilde{a}_{i n}\right)=\left(1-\prod_{j=1}^{n}\left(1-t_{\tilde{a}_{i(j)}}\right)^{\mu\left(A_{(j)}\right)-\mu\left(A_{(j+1)}\right)}, \prod_{j=1}^{n}\left(f_{\tilde{a}_{i(j)}}\right)^{\mu\left(A_{(j)}\right)-\mu\left(A_{(j+1)}\right)}\right)
$$

Aggregate all $\tilde{a}_{i j}=\left(t_{i j}, f_{i j}\right)(j=1,2, \ldots, n)$ in the $i$ th line of the intuitionistic fuzzy decision matrix into overall values $\tilde{a}_{i}=\left(t_{\tilde{a}_{i}}, f_{\tilde{a}_{i}}\right)=\operatorname{IFC} C_{\mu}\left(\tilde{a}_{i 1}, \ldots, \tilde{a}_{i n}\right)(i=1,2, \ldots, m)$ of the alternatives $\tilde{a}_{i}$, where $A_{(j)}=(j=1,2, \ldots, n), A_{(n+1)}=\varphi$.

Step 5. According to the overall values $\tilde{a}_{i j}=\left(t_{i j}, f_{i j}\right)$ of the alternative $a_{i}(i=1,2, \ldots, m)$, calculate the score function $S\left(\tilde{a}_{i}\right)$ or the accuracy degree $H\left(\tilde{a}_{i}\right)$ to rank the alternative $a_{i}(i=1,2, \ldots, m)$, which is similar to Step 2, then, select the best one.

Step 6. End.

\subsection{IVIFC integral operator-based method for decision-making}

The basic steps of the decision-making methodology with IVIF, which is extracted from $\mathrm{Xu}$ (2010) is similar to MCDM with the IFC integral operator proposed by Tan and Chen (2010) but their difference is on the Choquet integral operator is used in Step 4 which is shown below:

$$
\begin{aligned}
& \operatorname{IVIFCA}\left(\tilde{\alpha}\left(x_{1}\right), \tilde{\alpha}\left(x_{2}\right), \ldots, \tilde{\alpha}\left(x_{n}\right)\right)=
\end{aligned}
$$

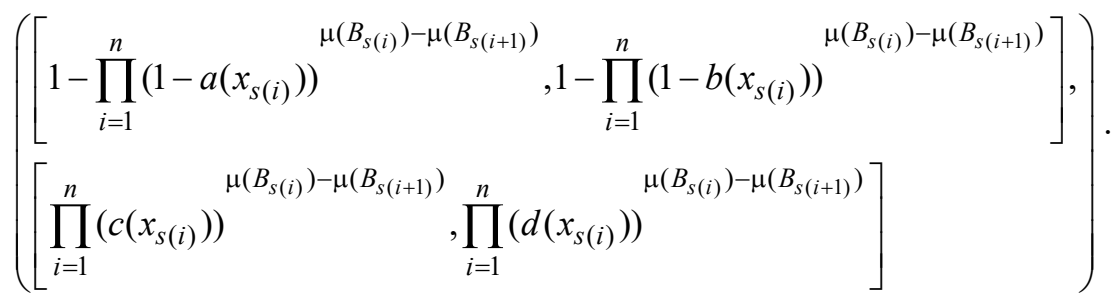




\section{Case study}

Automobile manufacturing is one of the key industries in Iran besides petrochemical and food industries. Based on car production statistics presented by the International Organisation of Motor Vehicle Manufacturers, Iranian manufacturers increased their production number from 119419 to 1090846 between 1999 and 2014 (Anon 2016a, 2016b). Due to the growth in the number of both car produced per year and car manufacturing companies in Iran, the environmental issues have received considerable attention in recent years. This study has been implemented in a factory which is the main supplier for a well-known Iranian car manufacturer. We try to consider both green supplier criteria and sustainable supplier criteria beside the usual criteria to evaluate and rank four candidate suppliers based on the proposed methodology to find out, which one is the most appropriate with regard to environmental criteria.

\section{Results and discussion}

\subsection{Results}

\subsubsection{Modified Delphi method}

The modified Delphi method was used to determine the criteria. A group of 5 managers comprised an expert panel to specify the criteria. The evaluation criteria for suppliers were collected through a literature review of GSCM and SSCM articles listed in Table 1. Then, the expert panel reached a consensus on the criteria related to the condition of the firm. The criteria were divided into 6 groups: Cost (C1), Time (C2), Delivery (C3), Quality (C4), Green principles (C5) and Social responsibility (C6). They also determined candidate suppliers as A1, A2, A3 and A4. We have arranged the criteria based on three dimensions of sustainability. Table 3 presents the details discussed.

Table 3. Criteria and sub-criteria for supplier selection

\begin{tabular}{|c|c|c|c|}
\hline $\begin{array}{l}\text { Sustainability } \\
\text { dimensions }\end{array}$ & Criteria & & Sub-criteria \\
\hline \multirow[t]{4}{*}{ Economic } & Cost & $\mathrm{C} 1$ & $\begin{array}{l}\text { Production cost, Transportation cost, Recycling cost, } \\
\text { Financial capability }\end{array}$ \\
\hline & Time & $\mathrm{C} 2$ & Production time, Transportation time \\
\hline & Delivery & $\mathrm{C} 3$ & Lead time, Order fulfilment rate \\
\hline & Quality & $\mathrm{C} 4$ & Quality-related certificates, Reject rate, Quality assurance \\
\hline Environmental & $\begin{array}{l}\text { Green } \\
\text { principles }\end{array}$ & $\mathrm{C} 5$ & $\begin{array}{l}\text { Pollution control, Elimination of hazardous elements, } \\
\text { Reverse logistic management, Green image, packaging, } \\
\text { Environmental friendly technology, Environmental } \\
\text { certificates }\end{array}$ \\
\hline Social & $\begin{array}{l}\text { Social } \\
\text { responsibility }\end{array}$ & C6 & $\begin{array}{l}\text { Social responsibility, Management commitment, } \\
\text { Rights of stakeholders, Information disclosure }\end{array}$ \\
\hline
\end{tabular}




\subsubsection{Decision-making with the IFC integral operator}

Step 1. In the first step, i.e. the partial evaluation of the alternative is made according to the six criteria. Ten experts were invited to evaluate the candidate suppliers. For example, the fuzzy evaluating value of criteria $\mathrm{C} 2$ of the candidate A1, can be expressed by the intuitionistic fuzzy value $(0.6,0.3)$ because six of the experts think that A1 is strong for the criteria $\mathrm{C} 2$, three of experts think that A1 is weak for the criteria $\mathrm{C} 2$, and one of them does not give a judgement on the criteria $\mathrm{C} 2$. The result of Step 1 is displayed in Table 4.

Table 4. IFVs decision matrix of alternative suppliers

\begin{tabular}{ccccccc}
\hline & $\mathrm{C} 1$ & $\mathrm{C} 2$ & $\mathrm{C} 3$ & $\mathrm{C} 4$ & $\mathrm{C} 5$ & $\mathrm{C} 6$ \\
\hline $\mathrm{A} 1$ & $(0.5,0.4)$ & $(0.6,0.3)$ & $(0.6,0.2)$ & $(0.5,0.3)$ & $(0.5,0.5)$ & $(0.4,0.5)$ \\
\hline $\mathrm{A} 2$ & $(0.4,0.5)$ & $(0.5,0.4)$ & $(0.6,0.1)$ & $(0.7,0.2)$ & $(0.2,0.6)$ & $(0.4,0.4)$ \\
\hline $\mathrm{A} 3$ & $(0.8,0.1)$ & $(0.6,0.2)$ & $(0.7,0.3)$ & $(0.7,0.2)$ & $(0.6,0.3)$ & $(0.5,0.2)$ \\
\hline A4 & $(0.6,0.2)$ & $(0.5,0.2)$ & $(0.7,0.1)$ & $(0.5,0.3)$ & $(0.4,0.5)$ & $(0.5,0.3)$ \\
\hline
\end{tabular}

Step 2. In the second step, the IFVs were reordered based on the calculated score and accuracy degrees (Table 5).

Table 5. Reordered IFVs

\begin{tabular}{ccccccc}
\hline & $\mathrm{C} 1$ & $\mathrm{C} 2$ & $\mathrm{C} 3$ & $\mathrm{C} 4$ & $\mathrm{C} 5$ & $\mathrm{C} 6$ \\
\hline $\mathrm{A} 1$ & $(0.4,0.5)$ & $(0.5,0.5)$ & $(0.5,0.4)$ & $(0.5,0.3)$ & $(0.6,0.3)$ & $(0.6,0.2)$ \\
\hline $\mathrm{A} 2$ & $(0.2,0.6)$ & $(0.4,0.5)$ & $(0.4,0.4)$ & $(0.5,0.4)$ & $(0.6,0.1)$ & $(0.7,0.2)$ \\
\hline A3 & $(0.5,0.2)$ & $(0.6,0.3)$ & $(0.6,0.2)$ & $(0.7,0.3)$ & $(0.7,0.2)$ & $(0.8,0.1)$ \\
\hline A4 & $(0.4,0.5)$ & $(0.5,0.3)$ & $(0.5,0.3)$ & $(0.5,0.2)$ & $(0.6,0.2)$ & $(0.7,0.1)$ \\
\hline
\end{tabular}

Step 3. Fuzzy measures must be calculated after receiving the expert opinion about the share of each criterion on supplier competencies as illustrated in Table 6.

Step 4. In this step, the final IFVs of supplier evaluations are calculated by using the intuitionistic fuzzy Choquet integral operator (Eq. 14) and fuzzy measures (Table 6) which were used as weights of criteria. The produced IFVs are as follow: $(0.55,0.297)$, $(0.56,0.249),(0.72,0.166),(0.595,0.183)$ for A1, A2, A3 and A4.

Step 5. To select the best supplier, we compared the final result of step 4 based on their score and accuracy degrees. $(0.72,0.166)>(0.595,0.183)>(0.56,0.249)>(0.55$, $0.297)$ it means that $\mathrm{A} 3>\mathrm{A} 4>\mathrm{A} 2>\mathrm{A} 1$, so $\mathrm{A} 3$ is the best supplier. 
Table 6. Fuzzy measures of criteria

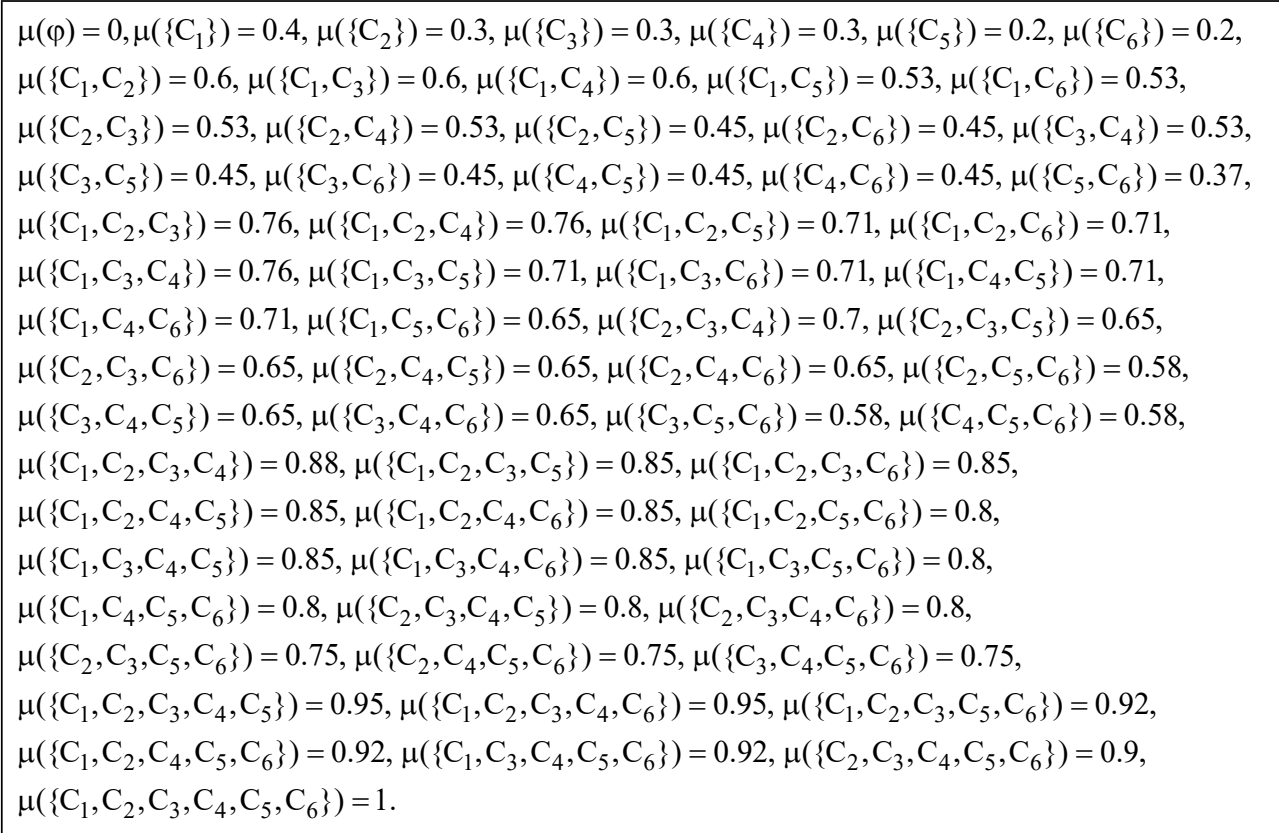

\subsubsection{Decision-making with the IVIFC integral operator}

Step 1. First, the experts were asked to evaluate the alternatives according to the six criteria by IVIFs or transform the IFVs of the previous section to IVIFs as in Table 7.

Table 7. IVIFs decision matrix of alternative suppliers

\begin{tabular}{ccccc}
\hline & $\mathrm{A} 1$ & $\mathrm{~A} 2$ & $\mathrm{~A} 3$ & $\mathrm{~A} 4$ \\
\hline $\mathrm{C} 1$ & $([0.5,0.6],[0.3,0.4])$ & $([0.2,0.4],[0.4,0.5])$ & $([0.7,0.8],[0.1,0.2])$ & $([0.5,0.7],[0.2,0.3])$ \\
\hline $\mathrm{C} 2$ & $([0.4,0.5],[0.2,0.4])$ & $([0.4,0.6],[0.2,0.4])$ & $([0.5,0.7],[0.1,0.3])$ & $([0.4,0.5],[0.1,0.3])$ \\
\hline C3 & $([0.5,0.7],[0.1,0.2])$ & $([0.6,0.7],[0,0.2])$ & $([0.6,0.7],[0.2,0.3])$ & $([0.5,0.7],[0.1,0.3])$ \\
\hline C4 & $([0.4,0.5],[0.3,0.4])$ & $([0.5,0.7],[0,0.2])$ & $([0.6,0.7],[0.1,0.2])$ & $([0.5,0.6],[0.2,0.3])$ \\
\hline C5 & $([0.3,0.5],[0.4,0.5])$ & $([0.1,0.3],[0.4,0.6])$ & $([0.5,0.6],[0.2,0.3])$ & $([0.3,0.5],[0.4,0.5])$ \\
\hline C6 & $([0.3,0.5],[0.3,0.5])$ & $([0.2,0.3],[0.6,0.7])$ & $([0.4,0.5],[0.2,0.3])$ & $([0.4,0.5],[0.2,0.3])$ \\
\hline
\end{tabular}

Step 2. After calculating the score and accuracy degrees, the IVIFs were reordered as shown in Table 8.

Table 8. Reordered IVIFs

\begin{tabular}{cccc}
\hline $\mathrm{A} 1$ & $\mathrm{~A} 2$ & $\mathrm{~A} 3$ & $\mathrm{~A} 4$ \\
\hline$([0.3,0.5],[0.4,0.5])$ & $([0.2,0.3],[0.6,0.7])$ & $([0.4,0.5],[0.2,0.3])$ & $([0.3,0.5],[0.4,0.5])$ \\
\hline$([0.3,0.5],[0.3,0.5])$ & $([0.1,0.3],[0.4,0.6])$ & $([0.5,0.6],[0.2,0.3])$ & $([0.4,0.5],[0.2,0.3])$ \\
\hline$([0.4,0.5],[0.3,0.4])$ & $([0.2,0.4],[0.4,0.5])$ & $([0.5,0.7],[0.1,0.3])$ & $([0.4,0.5],[0.1,0.3])$ \\
\hline$([0.4,0.5],[0.2,0.4])$ & $([0.4,0.6],[0.2,0.4])$ & $([0.6,0.7],[0.2,0.3])$ & $([0.5,0.6],[0.2,0.3])$ \\
\hline$([0.5,0.6],[0.3,0.4])$ & $([0.5,0.7],[0,0.2])$ & $([0.6,0.7],[0.1,0.2])$ & $([0.5,0.7],[0.2,0.3])$ \\
\hline$([0.5,0.7],[0.1,0.2])$ & $([0.6,0.7],[0,0.2])$ & $([0.7,0.8],[0.1,0.2])$ & $([0.5,0.7],[0.1,0.3])$ \\
\hline
\end{tabular}


Step 3 and 4. By using fuzzy measures (Table 6) and Supplier evaluation values, the final IVIFs are calculated through the Choquet integral operator (Eq. 15). The produced IVIFs are as follow: $([0.45,0.6],[0.205,0.336]),([0.44,0.6],[0,0.307])$, ([0.62,0.73],[0.12,0.235]), ([0.47,0.645],[0.155,0.308]) for A1, A2, A3 and A4.

Step 5. To select the best supplier, we compared the final result of Step 4 and rearranged it (based on the score and accuracy degrees). It means that A3 $>$ A2 $>$ A4 $>$ A1, so A3 is the best supplier.

\subsection{Discussion}

In this paper, an effective methodology to solve the supplier selection problem has been presented. The contribution of this paper is three-fold: (1) It can be counted among the scarce studies considering both economic (traditional) and sustainable (green) supplier selection criteria. (2) It is among the scarce studies utilising Choquet integral operators in two degrees of accuracy (IFVs \& IVIFs) in the context of the supplier selection. (3) It is among the scarce studies using Choquet integral operators and fuzzy measures for the green supplier evaluation problem. The presented methodology can extract the expert knowledge and improve the supplier selection process due to a high level of expert involvement in decision-making and the usage of Fuzzy-related concepts to cope with uncertainties. Moreover, the integration of the modified Delphi method by the researchers extends the degree, to which the fuzziness of a problem can be dealt with. The assessment of candidate suppliers in the context of IFVs and IVIFs can be easily made, which is very useful for application in the real world. Since the Choquet integral operators can capture both the element's importance and the interdependencies between elements (Tan, Chen 2010; Xu 2010), the proposed methodology is applicable in every selection process in the real world, which inherently features dependencies or interactions among criteria. Also, the proposed methodology provided a list of criteria for a supplier selection, which could be helpful for firms in the car-making industry and their suppliers. Although this methodology is capable of dealing with a large number of criteria and sub-criteria, due to the complexity of calculating fuzzy measures for large numbers, which result in exponentially increasing of subsets, it is better to increase the number of sub-criteria to be evaluated under the criteria titles by the expert opinion. The use of this systematic process for supplier selection, which has relied on the expert judgment significantly improved the supplier selection process in our case study firm and added some insight into the issue which is relevant to firms on a constant basis.

\section{Conclusions}

In this study, the authors have investigated the supplier selection issue considering both conventional and green criteria. The use of both conventional and green criteria helps companies to achieve their goals in order to protect the environment and produce less polluting products and engage in greener SC activities. In the proposed methodology, after reviewing the literature comprehensively, the Delphi method has been used to collect proper criteria based on expert opinion. The subjective nature of judgment in the supplier selection paved the way to utilise the intuitionistic fuzzy sets to cope with the fuzzy 
nature and uncertainty of this selection. In fact, the experts can express their opinion on suppliers by a membership degree and a non-membership degree in the form of IFV or with an interval membership degree and an interval non-membership degree in the form of IVIF. The importance of criteria has been determined by fuzzy measures. Moreover, some operators have been used for aggregating IFVs and IVIFs with correlative weights based on the Choquet integral, which is able to consider both the elements of importance and the correlations among the elements. Although the Choquet integral operator is not a new tool for decision-making, fuzzy operators are concluded from it and are now prevalent and developing quickly. A proper case study has also been provided to test the applicability of the proposed method. Future studies can further deal with the difficulties of determining the weights for the aggregating operator using techniques of weight determination that can capture correlations or dependencies among the criteria. The proposed methodology can also be used in every selection process that contains fuzziness naturally and will occur in an environment with correlated preferences.

\section{References}

Ahi, P.; Searcy, C. 2013. A comparative literature analysis of definitions for green and sustainable supply chain management, Journal of Cleaner Production 52: 329-341.

http://doi.org/10.1016/j.jclepro.2013.02.018

Amindoust, A.; Ahmed, S.; Saghafinia, A.; Bahreininejad, A. 2012. Sustainable supplier selection: a ranking model based on fuzzy inference system, Applied Soft Computing 12(6): 1668-1677. http://doi.org/10.1016/j.asoc.2012.01.023

Anon. 2016a. 1999 Statistics | OICA [online], [cited 20 May 2016]. Available from Internet: http://www.oica.net/category/production-statistics/1999-statistics/

Anon. 2016b. 2014 Statistics | OICA [online], [cited 20 May 2016]. Available from Internet: http://www.oica.net/category/production-statistics/2014-statistics./

Ashayeri, J.; Tuzkaya, G.; Tuzkaya, U. R. 2012. Supply chain partners and configuration selection: an intuitionistic fuzzy Choquet integral operator based approach, Expert Systems with Applications 39(3): 3642-3649. http://doi.org/10.1016/j.eswa.2011.09.055

Awasthi, A.; Chauhan, S. S.; Goyal, S. K. 2010. A fuzzy multicriteria approach for evaluating environmental performance of suppliers, International Journal of Production Economics 126(2): 370-378. http://doi.org/10.1016/j.ijpe.2010.04.029

Awasthi, A.; Govindan, K. 2016. Green supplier development program selection using NGT and VIKOR under fuzzy environment, Computers \& Industrial Engineering 91: 100-108. doi:10.1016/j.cie.2015.11.011

Azadnia, A. H.; Saman, M. Z. M.; Wong, K. Y.; Ghadimi, P.; Zakuan, N. 2012. Sustainable supplier selection based on self-organizing map neural network and multi criteria decision making approaches, Procedia - Social and Behavioral Sciences 65: 879-884.

http://doi.org/10.1016/j.sbspro.2012.11.214

Bai, C.; Sarkis, J. 2010. Green supplier development: analytical evaluation using rough set theory, Journal of Cleaner Production 18(12): 1200-1210. http://doi.org/10.1016/j.jclepro.2010.01.016

Bai, C.; Sarkis, J.; Wei, X. 2010. Addressing key sustainable supply chain management issues using rough set methodology, Management Research Review 33(12): 1113-1127.

http://dx.doi.org/10.1108/01409171011092176

Banaeian, N.; Mobli, H.; Fahimnia, B.; Nielsen, I. E.; Omid, M. 2016. Green supplier selection using fuzzy group decision making methods: a case study from the agri-food industry, Computers \& Operations Research. (in press) http://dx.doi.org/10.1016/j.cor.2016.02.015 
Beske, P.; Seuring, S. 2014. Putting sustainability into supply chain management, Supply Chain Management 19(3): 322-331. http://dx.doi.org/10.1108/SCM-12-2013-0432

Büyüközkan, G.; Çifçi, G. 2011. A novel fuzzy multi-criteria decision framework for sustainable supplier selection with incomplete information, Computers in Industry 62(2): 164-174.

http://doi.org/10.1016/j.compind.2010.10.009

Büyüközkan, G.; Çifçi, G. 2012. A novel hybrid MCDM approach based on fuzzy DEMATEL, fuzzy ANP and fuzzy TOPSIS to evaluate green suppliers, Expert Systems with Applications 39(3): 3000-3011. http://doi.org/10.1016/j.eswa.2011.08.162

Chai, J.; Liu, J. N. K.; Ngai, E. W. T. 2013. Application of decision-making techniques in supplier selection: a systematic review of literature, Expert Systems with Applications 40(10): 3872-3885. http://doi.org/10.1016/j.eswa.2012.12.040

Chen, T.-Y.; Wang, J.-C. 2001. Identification of $\lambda$-fuzzy measures using sampling design and genetic algorithms, Fuzzy Sets and Systems 123: 321-341.

Chen, T.; Wang, J.; Tzeng, G. 2000. Identification of general fuzzy measures by genetic algorithms based on partial information, IEEE Transactions on Systems, Man, and Cybernetics 30(4): 517-528.

Chen, Y. J. 2011. Structured methodology for supplier selection and evaluation in a supply chain, Information Sciences 181(9): 1651-1670. http://doi.org/10.1016/j.ins.2010.07.026

Dao, V.; Langella, I.; Carbo, J. 2011. From green to sustainability: information technology and an integrated sustainability framework, The Journal of Strategic Information Systems 20(1): 63-79. http://doi.org/10.1016/j.jsis.2011.01.002

Darabi, S.; Heydari, J. 2016. An interval-valued hesitant fuzzy ranking method based on group decision analysis for green supplier selection, IFAC-PapersOnLine 49(2): 12-17.

http://dx.doi.org/10.1016/j.ifacol.2016.03.003

Dobos, I.; Vörösmarty, G. 2014. Green supplier selection and evaluation using DEA-type composite indicators, International Journal of Production Economics 157: 273-278.

http://dx.doi.org/10.1016/j.ijpe.2014.09.026.

Esfahbodi, A.; Zhang, Y.; Watson, G. 2016. Sustainable supply chain management in emerging economies: trade-offs between environmental and cost performance, International Journal of Production Economics, http://dx.doi.org/10.1016/j.ijpe.2016.02.013.

Freeman, J.; Chen, T. 2015. Green supplier selection using an AHP-Entropy-TOPSIS framework, Supply Chain Management: An International Journal 20(3): 327-340.

http://dx.doi.org/10.1108/SCM-04-2014-0142

Genovese, A.; Koh, S. L.; Bruno, G.; Bruno, P. 2010. Green supplier selection: a literature review and a critical perspective, in 8th International Conference on Supply Chain Management and Information Systems (SCMIS), 6-9 October 2001, Hong Kong, 1-6.

Ghorabaee, M. K.; Amiri, M.; Salehi Sadaghiani, J.; Hassani Goodarzi, G. 2014. Multiple criteria group decision-making for supplier selection based on COPRAS method with interval type-2 fuzzy sets, The International Journal of Advanced Manufacturing Technology 75(5-8): 11151130. http://doi.org/10.1007/s00170-014-6142-7

Govindan, K.; Khodaverdi, R.; Jafarian, A. 2013. A fuzzy multi criteria approach for measuring sustainability performance of a supplier based on triple bottom line approach, Journal of Cleaner Production 47: 345-354. http://doi.org/10.1016/j.jclepro.2012.04.014

Govindan, K.; Rajendran, S.; Sarkis, J.; Murugesan, P. 2015. Multi criteria decision making approaches for green supplier evaluation and selection: a literature review, Journal of Cleaner Production 98(1): 66-83. http://dx.doi.org/10.1016/j.jclepro.2013.06.046.

Grabisch, M. 1995. Fuzzy integral in multicriteria decision making, Fuzzy Sets and Systems 69(3): 279-298. http://doi.org/10.1016/0165-0114(94)00174-6 
Grabisch, M.; Kojadinovic, I.; Meyer, P. 2008. A review of methods for capacity identification in Choquet integral based multi-attribute utility theory. Applications of the Kappalab R package, European Journal of Operational Research 186(2): 766-785.

http://doi.org/10.1016/j.ejor.2007.02.025

Gumus, A. T. 2009. Evaluation of hazardous waste transportation firms by using a two-step fuzzy-AHP and TOPSIS methodology, Expert Systems with Applications 36: 4067-4074.

http://doi.org/10.1016/j.eswa.2008.03.013

Gupta, S.; Palsule-Desai, O. D. 2011. Sustainable supply chain management: review and research opportunities, IIMB Management Review 23(4): 234-245.

http://doi.org/10.1016/j.iimb.2011.09.002

Gurel, O.; Acar, A. Z.; Onden, I.; Gumus, I. 2015. Determinants of the green supplier selection, Procedia Social and Behavioral Sciences 181: 131-139.

http://dx.doi.org/10.1016/j.sbspro.2015.04.874.

Hashemi, S. H.; Karimi, A.; Tavana, M. 2015. An integrated green supplier selection approach with analytic network process and improved Grey relational analysis, International Journal of Production Economics 159: 178-191. http://dx.doi.org/10.1016/j.ijpe.2014.09.027.

Hassini, E.; Surti, C.; Searcy, C. 2012. A literature review and a case study of sustainable supply chains with a focus on metrics, International Journal of Production Economics 140(1): 69-82. http://doi.org/10.1016/j.ijpe.2012.01.042

Ho, W.; Xu, X.; Dey, P. K. 2010. Multi-criteria decision making approaches for supplier evaluation and selection: a literature review, European Journal of Operational Research 202(1): 16-24. http://doi.org/10.1016/j.ejor.2009.05.009

Hsu, C.-W.; Kuo, T.-C.; Chen, S.-H.; Hu, A. H. 2013. Using DEMATEL to develop a carbon management model of supplier selection in green supply chain management, Journal of Cleaner Production 56: 164-172. http://doi.org/10.1016/j.jclepro.2011.09.012

Hu, A. H.; Hsu, C. W. 2010. Critical factors for implementing green supply chain management practice: an empirical study of electrical and electronics industries in Taiwan, Management Research Review 33(6): 586-608. http://dx.doi.org/10.1108/01409171011050208

Jain, V.; Wadhwa, S.; Deshmukh, S. G. 2009. Select supplier-related issues in modelling a dynamic supply chain: potential, challenges and direction for future research, International Journal of Production Research 47(11): 3013-3039.

Kannan, D.; Govindan, K.; Rajendran, S. 2015. Fuzzy Axiomatic Design approach based green supplier selection: a case study from Singapore, Journal of Cleaner Production 96: 194-208. http://dx.doi.org/10.1016/j.jclepro.2013.12.076

Kannan, D.; Khodaverdi, R.; Olfat, L.; Jafarian, A.; Diabat, A. 2013. Integrated fuzzy multi criteria decision making method and multiobjective programming approach for supplier selection and order allocation in a green supply chain, Journal of Cleaner Production 47: 355-367. http://doi.org/10.1016/j.jclepro.2013.02.010

Kuo, R. J.; Wang, Y. C.; Tien, F. C. 2010. Integration of artificial neural network and MADA methods for green supplier selection, Journal of Cleaner Production 18(12): 1161-1170.

http://doi.org/10.1016/j.jclepro.2010.03.020

Larbani, M.; Huang, C.; Tzeng, G. 2011. A novel method for fuzzy measure identification, International Journal of Fuzzy Systems 13(1): 24-34.

Lee, A. H. I.; Kang, H.-Y.; Hsu, C.-F.; Hung, H.-C. 2009. A green supplier selection model for high-tech industry, Expert Systems with Applications 36(4): 7917-7927.

http://doi.org/10.1016/j.eswa.2008.11.052

Lee, T. R.; Phuong Nha Le, T.; Genovese, A.; Koh, L. S. 2011. Using FAHP to determine the criteria for partner's selection within a green supply chain: the case of hand tool industry in 
Taiwan, Journal of Manufacturing Technology Management 23(1): 25-55.

http://dx.doi.org/10.1108/17410381211196276

Murillo, J.; Guillaume, S.; Tapia, E.; Bulacio, P. 2013. Revised HLMS: a useful algorithm for fuzzy measure identification, Information Fusion 14(4): 532-540.

http://doi.org/10.1016/j.inffus.2013.01.002

Okoli, C.; Pawlowski, S. D. 2004. The Delphi method as a research tool: an example, design considerations and applications, Information \& Management 42(1): 15-29.

http://doi.org/10.1016/j.im.2003.11.002

Park, J. H.; Park, I. Y.; Kwun, Y. C.; Tan, X. 2011. Extension of the TOPSIS method for decision making problems under interval-valued intuitionistic fuzzy environment, Applied Mathematical Modelling 35(5): 2544-2556. http://doi.org/10.1016/j.apm.2010.11.025

Peng, J. 2012. Research on the optimization of green suppliers based on AHP and GRA, Journal of Information and Computational Science 9(1): 173-182.

Qin, J.; Liu, X. 2013. Study on interval intuitionistic fuzzy multi-attribute group decision making method based on Choquet integral, Procedia Computer Science 17: 465-472.

http://doi.org/10.1016/j.procs.2013.05.060

Rostamzadeh, R. 2014. A new approach for supplier selection using fuzzy MCDM, International Journal of Logistics Systems and Management 19(1): 91-114.

http://dx.doi.org/10.1504/IJLSM.2014.064026

Rostamzadeh, R.; Govindan, K.; Esmaeili, A.; Sabaghi, M. 2015. Application of fuzzy VIKOR for evaluation of green supply chain management practices, Ecological Indicators 49: 188-203. http://doi.org/10.1016/j.ecolind.2014.09.045

Sahu, N. K.; Datta, S.; Mahapatra, S. S. 2012. Establishing green supplier appraisement platform using grey concepts, Grey Systems: Theory and Application 2(3): 395-418.

http://dx.doi.org/10.1108/20439371211273276

Sarkis, J.; Zhu, Q.; Lai, K. H. 2011. An organizational theoretic review of green supply chain management literature, International Journal of Production Economics 130(1): 1-15.

http://doi.org/10.1016/j.ijpe.2010.11.010

Seuring, S.; Müller, M. 2008. From a literature review to a conceptual framework for sustainable supply chain management, Journal of Cleaner Production 16(15): 1699-1710.

http://doi.org/10.1016/j.jclepro.2008.04.020

Shemshadi, A.; Shirazi, H.; Toreihi, M.; Tarokh, M. J. 2011. A fuzzy VIKOR method for supplier selection based on entropy measure for objective weighting, Expert Systems with Applications 38(10): 12160-12167. http://doi.org/10.1016/j.eswa.2011.03.027

Shen, L.; Olfat, L.; Govindan, K.; Khodaverdi, R.; Diabat, A. 2013. A fuzzy multi criteria approach for evaluating green supplier's performance in green supply chain with linguistic preferences, Resources, Conservation and Recycling 74: 170-179.

http://doi.org/10.1016/j.resconrec.2012.09.006

Shieh, J.-I.; Wu, H.-H.; Liu, H.-C. 2009. Applying a complexity-based Choquet integral to evaluate students' performance, Expert Systems with Applications 36: 5100-5106.

http://doi.org/10.1016/j.eswa.2008.06.003

Srivastava, S. K. 2007. Green supply-chain management: a state-of-the-art literature review, International Journal of Management Reviews 9(1): 53-80.

http://doi.org/10.1111/j.1468-2370.2007.00202.x

Srivastava, S.; Singh, M.; Madasu, V. K.; Hanmandlu, M. 2008. Choquet fuzzy integral based modeling of nonlinear system, Applied Soft Computing 8(2): 839-848.

http://doi.org/10.1016/j.asoc.2007.07.001 
Tachizawa, E. M.; Gimenez, C.; Sierra, V. 2015. Green supply chain management approaches: drivers and performance implications, International Journal of Operations \& Production Management 35(11): 1546-1566. http://dx.doi.org/10.1108/IJOPM-01-2015-0023

Takahagi, E. 2008. A fuzzy measure identification method by diamond pairwise comparisons and $\varphi$ s transformation, Fuzzy Optimization and Decision Making 7(3): 219-232.

http://dx.doi.org/10.1007/s10700-008-9032-3

Tan, C. 2011. A multi-criteria interval-valued intuitionistic fuzzy group decision making with Choquet integral-based TOPSIS, Expert Systems with Applications 38(4): 3023-3033.

http://doi.org/10.1016/j.eswa.2010.08.092

Tan, C.; Chen, X. 2010. Intuitionistic fuzzy Choquet integral operator for multi-criteria decision making, Expert Systems with Applications 37(1):149-157.

http://doi.org/10.1016/j.eswa.2009.05.005

Thongchattu, C.; Siripokapirom, S. 2010. Green supplier selection consensus by neural network, in ICMEE 2010 - 2010 2nd International Conference on Mechanical and Electronics Engineering, Proceedings 2: 313-316. http://doi.org/10.1109/ICMEE.2010.5558417

Tuzkaya, G. 2013. An intuitionistic fuzzy Choquet integral operator based methodology for environmental criteria integrated supplier evaluation process, International Journal of Environmental Science and Technology 10(3): 423-432. http://doi.org/10.1007/s13762-013-0180-9

Tuzkaya, G.; Ozgen, A.; Ozgen, D.; Tuzkaya, U. R. 2009. Environmental performance evaluation of suppliers: a hybrid fuzzy multi-criteria decision approach, International Journal of Environmental Science \& Technology 6(3): 477-490. http://doi.org/10.1007/BF03326087

Wang, X.-Z.; He, Y.-L.; Dong, L.-C.; Zhao, H.-Y. 2011. Particle swarm optimization for determining fuzzy measures from data, Information Sciences 181(19): 4230-4252.

http://doi.org/10.1016/j.ins.2011.06.002

Wu, C.; Barnes, D. 2011. A literature review of decision-making models and approaches for partner selection in agile supply chains, Journal of Purchasing and Supply Management 17(4): 256-274. http://doi.org/10.1016/j.pursup.2011.09.002

Wu, Y.; Geng, S.; Zhang, H.; Gao, M. 2014. Decision framework of solar thermal power plant site selection based on linguistic Choquet operator, Applied Energy 136: 303-311.

http://dx.doi.org/10.1016/j.apenergy.2014.09.032.

$\mathrm{Xu}, \mathrm{Z}$. 2010. Choquet integrals of weighted intuitionistic fuzzy information, Information Sciences 180(5): 726-736. http://doi.org/10.1016/j.ins.2009.11.011

Yeh, W.-C.; Chuang, M.-C. 2011. Using multi-objective genetic algorithm for partner selection in green supply chain problems, Expert Systems with Applications 38(4): 4244-4253.

http://doi.org/10.1016/j.eswa.2010.09.091

Yu, J.-H; Jeon, M.-J.; Kim, T. W. 2015. Fuzzy-based composite indicator development methodology for evaluating overall project performance, Journal of Civil Engineering and Management 21(3): 343-355. http://dx.doi.org/10.3846/13923730.2014.890644

Yu, Q.; Hou, F. 2016. An approach for green supplier selection in the automobile manufacturing industry, Kybernetes 45(4): 571-588. http://dx.doi.orug/10.1108/K-01-2015-0034

Zavadskas, E. K.; Antucheviciene, J.; Hajiagha, S. H. R.; Hashemi, S. S. 2014. Extension of weighted aggregated sum product assessment with interval-valued intuitionistic fuzzy numbers (WASPAS-IVIF), Applied Soft Computing 24: 1013-1021.

http://dx.doi.org/10.1016/j.asoc.2014.08.031.

Zavadskas, E. K.; Antucheviciene, J.; Hajiagha, S. H. R.; Hashemi, S. S. 2015. The interval-valued intuitionistic fuzzy MULTIMOORA method for group decision making in engineering, Mathematical Problems in Engineering, Article ID 560690. http://dx.doi.org/10.1155/2015/560690 
Arash SHAHRYARI NIA is currently PhD candidate of operation and production management at the School of Management and Accounting of Allameh Tabataba'i University, Tehran, Iran. He is currently working on his $\mathrm{PhD}$ thesis on the Supply Chain Collaboration and Supply Chain Agility. He received his B.Sc in industrial management from the University of Isfahan and master's degree in production management from Allameh Tabataba'i University. He has been recognised as a top student at the master's and $\mathrm{PhD}$ level. His research interest areas include Supply Chain Management, Reliability Theory, Decision Making and Soft Operational Research.

Laya OLFAT is Dean of the School of Management and Accounting of Allameh Tabataba'i University, Tehran, Iran. She is Associate Professor of Operational Research \& Management in Industrial Management Department. She has been adviser and supervisor of numerous MSc \& PhD thesis projects. She is Editor-in-Chief, a member of the Editorial Board and Reviewer of various Iranian \& International management journals. Her research interests include Supply Chain Management, Production and Inventory Planning, Project Management, Production Management Systems and Outsourcing.

Ahmad ESMAEILI is currently $\mathrm{PhD}$ candidate of operation and production management at the School of Management and Accounting of Allameh Tabataba'i University, Tehran, Iran. He is currently working on his $\mathrm{PhD}$ thesis on the capabilities regarding CoPS. He has published papers with the focus on supply chain management, multi criteria decision-making, service operations management and strategic management. He is a reviewer for various national and international journals. His research interests include: decision -making theories, supply chain management, qualitative research methods, sustainability issues in supply chain management, quality management, logistics, and service industry.

Reza ROSTAMZADEH is a doctor, currently a lecturer at Islamic Azad University of Urmia. He is the author and co-author of more than 10 research papers and reviewer of the several distinguished journals. His research interests include supply chain management, multi-criteria decision-making, operations management and entrepreneurship.

Jurgita ANTUCHEVIČIENĖ is Professor at the Department of Construction Technology and Management of Vilnius Gediminas Technical University, Vilnius, Lithuania. She received a PhD in Civil Engineering in 2005. She is author and co-author of about 80 scientific papers. Research interests include multiple criteria analysis, decision-making theories and decision support systems, sustainable development, construction management and investment. 